\title{
Trimethylaluminum-Mediated Peptide Synthesis
}

Peptide Chemistry

Key words

trimethylaluminum

solution-phase

synthesis<smiles>COC(=O)OC</smiles><smiles>[R]C(N)C(=O)O</smiles><smiles>CC(C)CCCCC(C)C</smiles><smiles>[R7]C([R])NC([R])C(=O)O</smiles>

(3 equiv)

$\mathrm{CH}_{2} \mathrm{Cl}_{2}$, reflux, 6-10 h

\begin{tabular}{|c|c|c|c|c|}
\hline Entry & Ester & $\mathrm{H}-\mathrm{Xaa}-\mathrm{OH}$ & $\mathrm{R}-\mathrm{CO}-\mathrm{Xaa}-\mathrm{OH}$ & Yield (\%) \\
\hline 1 & $\mathrm{PhCO}_{2} \mathrm{Me}$ & Phe & PhCO-Phe-OH & 77 \\
\hline 2 & $\mathrm{PrCO}_{2} \mathrm{Me}$ & Phe & PrCO-Phe-OH & 69 \\
\hline 3 & $\gamma$-butyrolactone & Pro & $\mathrm{HO}\left(\mathrm{CH}_{2}\right)_{3} \mathrm{CO}$-Pro-OH & 64 \\
\hline 4 & $\gamma$-butyrolactone & Phe & $\mathrm{HO}\left(\mathrm{CH}_{2}\right)_{3} \mathrm{CO}-\mathrm{Phe}-\mathrm{OH}$ & 67 \\
\hline 5 & $\gamma$-butyrolactone & Phe-Leu & $\mathrm{HO}\left(\mathrm{CH}_{2}\right)_{3} \mathrm{CO}-\mathrm{Phe}-\mathrm{Leu}-\mathrm{OH}$ & 59 \\
\hline 6 & $\mathrm{MeCO}_{2}$-Phe-OMe & Phe & $\mathrm{MeCO}_{2}$-Phe-Phe-OH & 60 \\
\hline 7 & Boc-Phe-OMe & Val & Boc-Phe-Val-OH & 50 \\
\hline 8 & Boc-Phe-OMe & Phe & Boc-Phe-Phe-OH & $45(<1)^{\mathrm{a}}$ \\
\hline 9 & Boc-Val-OMe & Val & Boc-Val-Val-OH & 37 \\
\hline 10 & Boc-Val-OMe & Phe & Boc-Val-Phe-OH & 31 \\
\hline 11 & Boc-Phe-OMe & Phe-Leu & Boc-Phe-Phe-Leu-OH & $42(<3 \%)^{b}$ \\
\hline
\end{tabular}

peptide coupling

unprotected amino acids

Significance: The amide bond is ubiquitous; in particular, it is present in the backbones of peptides and in many natural products. Consequently, it has gained considerable importance in organic synthesis. Chemists are therefore continually searching for new methods for amide and/or peptide bondforming reactions. In 1998, Martin and co-workers invented an $\mathrm{AlMe}_{3}$-mediated peptide synthesis from unprotected amino acids in the solution phase.
Comment: This inexpensive AlMe 3 -mediated solution-phase amide bond forming reaction proceeds smoothly to afford the desired products in moderate to good yields. The method can also be applied in syntheses of tripeptides in moderate yields. 